\title{
LEARNING ISLAMIC RELIGIOUS EDUCATION DURING THE COVID-19 PANDEMIC
}

\author{
Darmi \\ MIN 5 Talang Empat, Bengkulu Tengah, Indonesia \\ Email: nuruldarmi@gmail.com
}

\begin{abstract}
The Covid-19 pandemic has caused many changes in the education sector; learning is currently being carried out by paying attention to social distancing, resulting in very significant changes in learning methods. Learning Islamic Religious Education is one that is affected by this. The purpose of this article is to find out how the learning process of Islamic Religious Education during the Covid-19 pandemic, the learning media used, the effectiveness of learning, and the challenges faced. The research method used is library research, where this article will describe the latest and updated conditions of Islamic Religious Education learning. The results showed that learning Islamic Religious Education was carried out without face-to-face. Learning was carried out online, starting from the elementary school level to college; only at the early childhood level learning was carried out at home. The learning media used are entirely technology-based by utilizing the internet. The effectiveness of learning cannot be concluded because of the lack of data sources. The big challenge faced is the decline in student morale when learning is done online. It takes a special good learning format for learning Islamic Religious Education so that the learning objectives can be achieved.
\end{abstract}

Keywords: Learning, Islamic Religious Education, the Covid-19 Pandemic

\begin{abstract}
Abstrak: Pandemi covid-19 telah menyebabkan banyak perubahan di sektor pendidikan, pembelajaran saat ini dilakukan dengan memperhatikan sosial distancing, sehingga terjadi perubahan cara belajar yang sangat signifikan. Pembelajaran Pendidikan Agama Islam (PAI) merupakan salah satu yang terdampak akan hal ini. Tujuan artikel ini adalah untuk mengetahui bagaimana proses pembelajaran Pendidikan Agama Islam selama pandemi Covid-19, media pembelajaran yang digunakan, kefektifan pembelajaran, serta tantangan yang dihadapi. Metode penelitian yang digunakan adalah penelitian pustaka, dimana artikel ini akan menggambarkan keadaan terbaru dan terupdate dari pembelajaran Pendidikan Agama Islam. Hasil penelitian menunjukkan bahawa pembelajaran Pendidikan Agama Islam dilakukan dengan tanpa tatap muka, pembelajaran dilakukan secara daring mulai dari tingkat Sekolah Dasar hingga perguruan tinggi, hanya pada jenjang anak usia dini pembelajaran dilakukan dirumah. Media pembelajaran yang digunakan seluruhnya berbasis teknologi dengan memanfaatkan internet. Keefektifan pembelajaran belum bisa disimpulkan karena masih kurangnya sumber data. Tantangan besar yang dihadapi berupa menurunnya moral siswa saat pembelajaran dilakukan secara daring. Dibutuhkan sebuah format pembelajaran yang baik khusus untuk pembelajaran Pendidikan Agama Islam, agar tujuan pembelajarannya dapat tercapai.
\end{abstract}

Kata Kunci: Pembelajaran, Pendidikan Agama Islam, Pandemi Covid-19

\section{INTRODUCTION}

The outbreak of the Covid-19 pandemic around the world, including in Indonesia, has brought enormous changes in education. The world of education seems to make the house an educational institution that can replace formal educational institutions (Syah, 2020). Learning is currently carried out by paying attention to health protocols so that face-to-face learning is eliminated (Widiyono, 2020). Learning eventually inevitably took place at home, but not with the teacher's arrival to each student's house but with online 
media. Current learning using the internet network is commonly referred to as ELearning, or also known as online learning (online) (Meidawati, 2019). This online learning puts high pressure on teacher teaching activities; not even a few teachers have to spend extra energy to implement online learning as desired (Barseli et al., 2018).

In Islamic Religious Education as part of religious education that increases faith and piety as well as noble morals to enlighten the life of the nation as well as a very important role in shaping the character of the nation (Anam, 2017). The Covid-19 pandemic is currently spreading, so it is feared that changing the way of learning to online learning will cause the learning objectives of Islamic Religious Education not to be achieved. Livana's research said that online learning causes stress when studying (Livana, Mubin Mohammad Fatkhul \& Basthomi, 2020). The effectiveness of learning must also be considered because learning that is not effective will not produce good learning outcomes. Research conducted by Wisdom shows that online learning is only effective in certain subjects (Hikmat et al., 2020). It shows that online learning that has taken place has not been effective in all subjects. The objectives of writing this article are: (1) to determine the implementation of Islamic Religious Education learning during the Covid19 Pandemic; (2) to find out the learning media used in Islamic Education subjects during the Covid-19 Pandemic; (3) to determine the effectiveness of Islamic Education learning during the Covid-19 Pandemic; and (4) to determine the challenges of learning Islamic education during the Covid-19 Pandemic.

\section{LITERATURE REVIEW}

\section{Islamic Religious Education Learning}

Religious learning is in general learning, which must be practised at all education levels, from early to the high school level. Islamic studies are defined in Madrasah in four topics: Aqidah Akhlak, Quran Hadith, Fiqh, and Islamic Cultural History. While in Islamic schools, only one subject called Islamic religious education and ethics is mentioned. Islamic religious education is primarily aimed at giving students spiritual significance. Its presence shapes the personality of a Muslim, a believer, and also fears Allah SWT so that this type of Islamic learning does not only take the form of principles but also of practices that require an individual to be skilled and habituated to practising in Islam (D. Susanti, 2018). Since learning requires guidance, both in terms of understanding and skills, the teacher must be encouraged to carry out the learning in ways 
that can be done and accomplished uniformly by the number of students (Rustam Ibrahim, 2013). Also, the Covid-19 outbreak emergency requires distance learning. Of course, the teacher must innovate from face-to-face learning in E-Learning.

\section{Covid-19 Pandemic}

Coronavirus is a wide family of human and animal-attack viruses. The virus causes inflammatory diseases ranging from grip to extreme diseases such as the Middle East Respiratory Syndrome (MERS) and serious acute respiratory syndrome (SARS). A new form of coronavirus was detected in Wuhan at the end of 2019, Extreme Acute Respiratory Syndrome Coronavirus 2 (SARS-COV2), and Coronavirus Disease-2019 (Covid-19) (Dr. Safrizal ZA et al., 2020). Most citizens from many countries worldwide already have a pandemic called the Covid-19 outbreak in 2019 (Covid-19). According to the Language Development Agency of the Ministry of Education and Culture, neostandard, or in Indonesian, that is to say; modern normal is a normal condition that has never before existed or is new. It is because people must adjust to numerous new rules during the Covid-19 pandemic, such as wearing masks, always hand washing, and physical distance (Pusdiklat, 2020).

\section{RESEARCH METHODOLOGY}

This article uses the library research method to answer the problem formulation, while the data sources used are scientific articles originating from the National Journal in Indonesia. Article searches are carried out on google scholar with Harzing's Publish or Perish application. The articles that will be used as data sources are articles with the theme of Islamic religious education and Covid-19. The search was carried out using the words "Islamic Religious Education" and "Covid" to match the problem's formulation to be answered. The search for articles was carried out in November 2020; articles were limited to the year they were published in 2020; this is because the Covid-19 pandemic began to spread in 2020 . The articles found were 19 articles, then only 14 articles were used as data sources; this is because five manuscripts are not articles originating from journals. A list of journals and article titles that are data sources can be seen in Table 1.

Table 1. List of journal names and article titles

\begin{tabular}{cll}
\hline NO & \multicolumn{1}{c}{ Journal Name } & \multicolumn{1}{c}{ Article Title } \\
\hline 1 & AKTUALITA: Jurnal & Peran Media Sosial Dalam Pendidikan Dan \\
& penelitian sosial dan & Pengajaran Agama Islam Pada Masa Pandemi \\
\hline
\end{tabular}




\begin{tabular}{|c|c|c|}
\hline & keagamaan & Covid-19 \\
\hline 2 & $\begin{array}{l}\text { ATTA’DIB: Jurnal Pendidikan } \\
\text { Agama Islam }\end{array}$ & $\begin{array}{l}\text { Kemerosotan Moral Siswa Pada Masa Pandemic } \\
\text { Covid-19: Meneropong Eksistensi Guru } \\
\text { Pendidikan Agama Islam }\end{array}$ \\
\hline 3 & Edupedia & $\begin{array}{l}\text { Studi analisis dampak pademi Covid-19 } \\
\text { terhadap eksistensi pembelajaran pendidikan } \\
\text { Agama Islam di Indonesia }\end{array}$ \\
\hline 4 & $\begin{array}{l}\text { Fitrah: Journal of Islamic } \\
\text { Education }\end{array}$ & $\begin{array}{lll}\text { Pembelajaran Pendidikan Agama } & \text { Islam } \\
\text { Berbasis E-Learning } & & \\
\end{array}$ \\
\hline 5 & $\begin{array}{l}\text { GHAITSA: Islamic Education } \\
\text { Journal }\end{array}$ & $\begin{array}{l}\text { Strategi Alternatif Dalam Pembelajaran Daring } \\
\text { Pendidikan Agama Islam Pada Masa Pandemi } \\
\text { Covid-19 }\end{array}$ \\
\hline 6 & Inovasi Pendidikan & $\begin{array}{l}\text { Implementasi Pembelajaran Secara Daring Pada } \\
\text { Mata Pelajaran Pendidikan Agama Islam } \\
\text { Tingkat SMP Di Masa Pandemic Covid-19 }\end{array}$ \\
\hline 7 & $\begin{array}{l}\text { JCE (Journal of Childhood } \\
\text { Education) }\end{array}$ & $\begin{array}{l}\text { Pendidikan Agama Islam Dalam Keluarga } \\
\text { Sebagai Strategi Pendidikan Anak Usia Dini } \\
\text { Saat Pandemi Covid-19 }\end{array}$ \\
\hline 8 & Journal of Islamic Education & $\begin{array}{l}\text { Peran Dan Tantangan Pendidikan Agama Islam } \\
\text { Di Era Pandemi Covid-19 Pada Lingkungan } \\
\text { Keluarga }\end{array}$ \\
\hline 9 & Jurnal MUDARRISUNA & $\begin{array}{l}\text { Internalisasi Nilai Merdeka Belajar Dalam } \\
\text { Pembelajaran PAI Di Masa Pandemi Covid-19 }\end{array}$ \\
\hline 10 & Jurnal Pendidikan Islam & $\begin{array}{l}\text { Kesiapan Belajar Peserta Didik Terhadap Hasil } \\
\text { Pembelajaran Pendidikan Agama Islam (PAI) } \\
\text { Berbasis Daring Selama Pandemi Covid-19 Di } \\
\text { Smk Antartika } 2 \text { Sidoarjo }\end{array}$ \\
\hline 11 & Jurnal Tambora & $\begin{array}{l}\text { Efektifitas Media Pembelajaran Daring Edmodo } \\
\text { Dalam Perkuliahan Pendidikan Agama Islam } \\
\text { Pada Masa Pandemi Covid-19 }\end{array}$ \\
\hline 12 & $\begin{array}{l}\text { Maslahah Jurnal Pengabdian } \\
\text { Masyarakat }\end{array}$ & $\begin{array}{l}\text { Implementasi Pendidikan Agama Islam di Masa } \\
\text { Pandemi Covid-19 }\end{array}$ \\
\hline 13 & $\begin{array}{l}\text { SALAM : Jurnal Sosial \& } \\
\text { Budaya Syar-i }\end{array}$ & $\begin{array}{llr}\text { Analisis } & \text { Keefektivitasan Pemanfaatan E- } \\
\text { Learning } & \text { Sebagai Media Pembelajaran } \\
\text { Pendidikan Agama Islam Pada Masa Pandemi } \\
\text { Corona (Covid-19) }\end{array}$ \\
\hline 14 & $\begin{array}{l}\text { VICRATINA: Jurnal } \\
\text { Pendidikan Islam }\end{array}$ & $\begin{array}{l}\text { Pemanfaatan teknologi } \\
\text { pendidikan agama islam di tengah masa } \\
\text { pandemi Covid-19 berbasis social distancing di } \\
\text { SMKN 5 Malang }\end{array}$ \\
\hline
\end{tabular}

\section{FINDINGS AND DISCUSSION}

\section{Learning Islamic Religious Education during the Covid-19 Pandemic}

Learning at tertiary schools during the Covid-19 pandemic at the beginning of the odd semester in 2020 starts face to face with the outbreak of the pandemic; learning takes the form of online courses, independent research techniques, videos, assignments, and 
quizzes. Islamic Religious Education learning takes place in face-to-face and online lectures, which result in a hybrid model of online lectures since there are two face-to-face and online models (Larassati, 2020).

Electronic learning (e-learning) is learning that promotes face to face and online experiences. E-learning has different features; a) Readers cannot carry out face-to-face tasks up to 14 times. b) Internet-based activities designed in compliance with specific specifications shall be considered equal to face-to-face activities. c) Remote and face-toface tasks are configured alternately (Yuliana, 2020). Following the Covid-19 pandemic, the SMP 1 Pariaman formed social dissociations or physical distances to mitigate and secure SMP 1 Pariaman residents' spread of Covid-19. That is why a home learning strategy is developed by online learning (W. Susanti, 2020).

During the Covid-19 pandemic, online learning was introduced in school policy on Islamic Religious Education learning technology amid the Covid-19 pandemic centred on social separation at SMKN 5 Malang. This happened so quickly that many parties were either mentally or planning unprepared but had to deal with it. The school has developed an online learning facility. However, it frees any teacher from using other applications, which are considered easier for the KBM method. There will be no modifications to the curriculum or resources during online learning, but there will be unwritten changes to the learning process (Uun Almah, M. Ilyas Thohari, 2020).

Islamic Religious Education learning is carried out online; not all learning strategies can be applied in the Islamic Religious Education learning process. Several alternative strategies that are appropriate for achieving the learning objectives of Islamic Education include the following: (a) Inquiry / Guided Inquiry Learning, (b) Contextual Teaching Learning; and (c) Problem Based Learning (Giyarsi, 2020).

Islamic Religious Education learning at SMK Antartika 2 Sidoarjo was conducted online after the outbreak of the Covid-19 pandemic (Ahmad Busthomy MZ, 2020). Islamic Religious Education learning shifts from face-to-face learning to online-based learning (Dhaifi, 2020). E-Learning-based Islamic Religious Education is applied at MTS PAI Medan (Lubis \& Yusri, 2020). Islamic Religious Education learning during the Covid-19 pandemic that was implemented at SDN Rejosari 3 used the internalization of the value of independent learning (Suntoro \& Widoro, 2020). Islamic Religious Education learning in junior high school uses social media, social media users in the form of Facebook, Twitter, Instagram, path, WhatsApp (Muslimah, 2020). 
The presence of this Corona Virus exposes confusion in Indonesia and elsewhere in the current education system, both in schools and universities, in engaging in or generally called online learning activities. This online learning makes it harder for teachers to create learning materials such as YouTube accounts, bloggers, oral writing, and learning media which excite student excitement and stop them bored, as well as discipline for children like using the Whatsapp application to zoom or to Video Call (Yusuf et al., 2020). Learning Islamic Religious Education in early childhood is carried out with the help of parents at home, teaching the values and the role of religion in the life that a child will go through. (Achmad, 2020a)

Islamic religious education learning, which is applied in schools, starting from elementary school to university level, has shifted from face-to-face learning to face-toface learning. Face-to-face learning used in the form of electronic learning, often referred to as e-learning or online learning. In the process, online learning requires separate learning strategies and methods so that learning objectives can be maximally achieved. Islamic education learning, while using online concepts, can use PBL learning strategies, guided inquiry, and CTL. In the process, schools can use applications that were already available before the Covid-19 pandemic, such as social media applications and learning applications, but some schools build their websites to carry out online learning. Only at the early childhood education level, Islamic Religious Education learning is not carried out online but guided learning by parents at home.

\section{Learning Media Used}

Islamic Religious Education courses were administered online with Edmodo as a learning medium during the Covid-19 pandemic. The lecturers discuss the advantages of Edmodo to promote communication and learning, which enable students to remain excited about learning, but not in the form of face-to-face lectures due to the Covid-19 pandemic. Edmodo has the following phases during the Islamic Religious Education lecture process; (1) interact with students about Covid-19 and the importance of achieving learning results in any circumstances. There is an arrangement to use Edmodo software. (2) Professors build profiles as instructors, teachers, and educators so that students can enter their classes. (3) Students download an Edmodo application and enter a class based on the code they have created, singing, or registering with Edmodo. (4) Readers upload Edmodo account materials and tasks. (5) Students learn individually through the download of content, by commenting on or personal messages, and by 
uploading tasks on a date-line. (6) Readers observe the success of students. (7) Readers test online learning media with Edmodo through WhatsApp media during Islamic Education lectures (Larassati, 2020).

Learning media is used in the form of e-learning (Yuliana, 2020). When introducing online learning (in the network), zoom-meeting media can be used, but not all students can take other moves by taking advantage of WhatsApp and using learning images. Online learning requires that SMP 1 teachers use technology to play their active role to enable online learning programs to operate smoothly amid the Covid-19 pandemic. The teacher of Islamic religious education discloses that he uses online media like Google forms and Google slides by online learning (W. Susanti, 2020). During the pandemic, the use of Islamic Religious Education learning technology during the Covid19 pandemic based on social distancing at SMKN 5 Malang used as Web-based learning, google classroom, Edmodo, WhatsApp (Uun Almah, M. Ilyas Thohari, 2020)

Electronic media that use technology is the type of online learning media used in Islamic Education. The easiest media for students to operate are smartphones that have supporting applications, including WhatsApp, YouTube, Live Facebook, Email, group meeting applications (zoom, google meet, cloudX and others), google classroom, and google forms. You can also make use of ruang guru, Sekolah mu, Icando, Rumah Belajar, Meja Kita, IndonesiaX, Google for Education, Kelas Pintar, Zenius, etc. (Giyarsi, 2020). The use of multimedia learning in the form of images and videos relevant to students' daily lives (Lubis \& Yusri, 2020). The learning media used during online learning is the WhatsApp application, but in its use, students are assisted by parents; this is because students are not able to operate the WhatsApp application (Suntoro \& Widoro, 2020).

The learning media used during the Covid-19 pandemic in schools are varied, but one thing that has become the same is the use of technology. The learning media used are special educational learning media, such as Edmodo, google classroom, teacher's room, your class, study room, Zenius, smart class. Learning media, which has become a new trend, uses social media in learning, such as WhatsApp and Facebook. Learning media used for video conferencing are also used, such as zoom meetings, zoom meet, and cloud $\mathrm{x}$. Other learning media used in the form of email and google form are used to collect assignments. Also, there are learning media in the form of YouTube videos, pictures, and learning videos. If a similarity is taken, this learning media as a whole requires the internet to operate. 


\section{The Effectiveness of Islamic Education Learning During the Covid-19 Pandemic}

Analysis of the results of this interview can be concluded that online learning media using Edmodo is considered effective for carrying out the online learning process during the Covid-19 pandemic (Larassati, 2020). The effectiveness of the use of e-learning as a learning medium at STMIK Prabumulih is good enough, but the user security system and the password used still need to be improved in order to provide security (Yuliana, 2020).

Online learning was not used sufficiently for the completeness of student learning. In its application, there are still many hurdles. Just students with a strong desire to pursue, the rest are absent or submit only jobs but do not engage in online learning. Also, some students never attend and take up their jobs. Online learning is, therefore, not successful (W. Susanti, 2020). Based on the research results above, it cannot be concluded whether effective online learning has been implemented; more data is needed to draw these conclusions. Mainly because of the constraints faced during the learning process, so this cannot be concluded.

\section{Challenges of Learning Islamic Education During the Covid-19 Pandemic}

The responsibilities and challenges of parents in Islamic religious education through the family during the Covid-19 pandemic include taking an active role in the religious education and general education process. Secondly, be a role model in the family, in particular for its children. Third, make the best use of the advice, tales, incidents, or penalties in the 19th season. Fourthly, parents should prioritize their children's Islamic religious education content so that they can always abide by the standards of religious teaching in the exercise of life principles. Fifthly, in the Covid-19 pandemic, plans and methods should succeed in carrying out Islamic religious education in the family setting (Achmad, 2020b).

The emergence of the Covid-19 pandemic has indeed impacted the world of education, especially on interactions and learning patterns (Lubis \& Yusri, 2020). The degradation of the morality of children, particularly in MA Muhammadiyah Nangahure, is the product of the lack of care by parents, the lack of affection, the lack of a religious understanding, poor environmental influences, and the interaction of peers who are not in line with the social norms. This often leads to students behaving out of reason (Fatiha \& Nuwa, 2020).

The challenges faced during online learning are diverse, ranging from inadequate infrastructure; this also includes internet networks and quotas that burden parents. 
However, it does not stop there, the biggest challenge in Islamic religious education during online learning is the loss of interaction between teachers and students, which in Islamic Religious Education learning is a very important aspect because Islamic Religious Education Learning also serves as a moral shaper for students, so this will cause a moral deterioration in students.

\section{CONCLUSIONS}

Islamic Religious Education learning that is applied in schools from elementary to tertiary level uses online learning. Online learning is used to prevent the spread of the Covid-19 virus and maintain social distancing policies. The learning media used in Islamic Education learning vary according to their needs and needs, learning media in the form of social media, educational applications, to websites. The effectiveness of learning cannot be concluded because there is still a lack of articles that discuss it. The biggest challenge in learning Islamic education during the Covid-19 pandemic is in the form of decreasing student morale. It is necessary to find a special format for Islamic Education learning so that the values of Islamic Education learning are not reduced even though learning is still carried out online.

\section{REFERENCES}

Achmad, W. (2020a). Pendidikan Agama Islam Dalam Keluarga Sebagai Strategi Pendidikan Anak Usia Dini Saat Pandemi Covid-19. JCE (Journal of Childhood Education), 4(1), 71-83. https://doi.org/10.24036/108806

Achmad, W. (2020b). Peran dan Tantangan Pendidikan Agama Islam di Era Pandemi Covid-19 pada Lingkungan Keluarga. Journal Of Islamic Education, 5(2), 169182.

http://www.ejournal.stitmuhbangil.ac.id/index.php/jie/article/view/188

Ahmad Busthomy MZ, A. H. (2020). Kesiapan Belajar Peserta Didik Terhadap Hasil Pembelajaran Pendidikan Agama Islam (PAI) Berbasis Daring Selama Pandemi Covid-19 Di SMK Antartika 2 Sidoarjo. Pendidikan Islam, 8(3), 1-14. https://ojs.staituankutambusai.ac.id/index.php/hikmah/article/view/204

Anam, S. (2017). Karakteristik dan Sistem Pendidikan Islam: Mengenal Sejarah Pesantren, Surau dan Meunasah di Indonesia. JALIE: Journal of Applied Linguistics and Islamic Education, I(I), 146-167. https://doi.org/10.33754/jalie.v1i1.52

Barseli, M., Ahmad, R., \& Ifdil, I. (2018). Hubungan Stres Akademik Siswa dengan Hasil Belajar. Jurnal EDUCATIO: Jurnal Pendidikan Indonesia, 4(1), 40-47. https://doi.org/10.29210/120182136 
Dhaifi, I. (2020). Studi Analisis Dampak Pademi Covid-19 Terhadap Eksistensi Pembelajaran Pendidikan Agama Islam Di Indonesia. Edupedia, 5(1), 45-53. https://doi.org/10.35316/edupedia.v5i1.880

Dr. Safrizal ZA, Ms., Danang Insita Putra, P., Safriza Sofyan, SE, AK, M. C., \& MPH, D. B. (2020). Pedoman Umum Kesiapsiagaan Menghadapi Penyakit Coronavirus (2019-nCoV) untuk Pemerintah Daerah. In Tim Kerja Kementerian Dalam Negeri. Kementerian Dalam Negeri.

Fatiha, N., \& Nuwa, G. (2020). Kemerosotan Moral Siswa Pada Masa Pandemic Covid 19: Meneropong Eksistensi Guru Pendidikan Agama Islam. ATTA'DIB: Jurnal Pendidikan Agama Islam, 1(2), 1-17.

https://jurnal.iain-bone.ac.id/index.php/attadib/article/view/945

Giyarsi. (2020). Strategi Alternatif Dalam Pembelajaran Daring Pendidikan Agama Islam Pada Masa Pandemi Covid 19. GHAITSA : Islamic Education Journal, 1(3), 224244.

https://www.siducat.org/index.php/ghaitsa/article/view/108

Hikmat, Hermawan, E., Aldim, \& Irwandi. (2020). Efektivitas Pembalajaran Daring Selama Masa Pandemi Covid-19: Sebuah Survey Online. Digital Library, UIN Sunan Gunung Djati, Bandung, 1-7.

http://digilib.uinsgd.ac.id/30625/

Larassati, M. A. (2020). Efektifitas Media Pembelajaran Daring Edmodo Dalam Perkuliahan Pendidikan Agama Islam Pada Masa Pandemi Covid-19. Jurnal Tambora : Special Issue, 4(2A), 77-82.

http://jurnal.uts.ac.id/index.php/Tambora/article/view/777

Livana, Mubin Mohammad Fatkhul \& Basthomi, Y. (2020). Penyebab Stres Mahasiswa Selama Pandemi Covid-19. Jurnal Ilmu Keperawatan Jiwa, 3(2), 203-208. https://journal.ppnijateng.org/index.php/jikj/article/view/590

Lubis, M., \& Yusri, D. (2020). Pembelajaran Pendidikan Agama Islam Berbasis ELearning (Studi Inovasi Pendidik MTS PAI Medan di Tengah Wabah Covid-19). Fitrah: Journal of Islamic Education, 1(1), 1-18.

https://jurnal.staisumatera-medan.ac.id/index.php/fitrah/article/view/1

Meidawati, S. A. N. B. R. (2019). Persepsi Siswa Dalam Studi Pengaruh Daring Learning Terhadap Minat Belajar Ipa. SCAFFOLDING: Jurnal Pendidikan Islam Dan Multikulturalisme, 1(2), 30-38.

https://doi.org/10.37680/scaffolding.v1i2.117

Muslimah, M. (2020). Peran Media Sosial Dalam Pendidikan Dan Pengajaran Agama Islam Pada Masa Pandemi Covid 19. AKTUALITA Jurnal Penelitian Sosial Dan Keagamaan, 10(Juni), 40-59.

http://ejournal.annadwahkualatungkal.ac.id/index.php/aktualita/article/view/161

Pusdiklat. (2020). Surat Edaran Mendikbud No 4 Tahun 2020 tentang Pelaksanaan Kebijakan Pendidikan dalam Masa Darurat Penyebaran Corona Virus Disease (Covid-19). In Pusdiklat Pegawai Kementerian Pendidikan dan Kebudayaan.

Rustam Ibrahim. (2013). Pendidikan Multikultural: Pengertian, Prinsip, dan Relevansinya dengan Tujuan Pendidikan Islam. Addin, 7(1), 129-154.

http://dx.doi.org/10.21043/addin.v7i1.573 
Suntoro, R., \& Widoro, H. (2020). Internalisasi Nilai Merdeka Belajar Dalam Pembelajaran PAI Di Masa Pandemi Covid-19. Mudarrisuna, 10(2), 143-165. https://jurnal.ar-raniry.ac.id/index.php/mudarrisuna/article/view/7343

Susanti, D. (2018). Pengembangan Pendidikan Agama Islam. Edureligia; Jurnal Pendidikan Agama Islam, 1(2), 63-75.

https://doi.org/10.33650/edureligia.v1i2.46

Susanti, W. (2020). Pendidikan Agama Islam di Masa Pandemi Implementasi Pembelajaran Secara Daring Pada Mata Pelajaran Pendidikan Agama Islam Tingkat SMP Di Masa Pandemic Covid-19. Inovasi Pendidikan, 7(2), 134-145. http://jurnal.umsb.ac.id/index.php/inovasipendidikan/article/view/2311

Syah, R. H. (2020). Dampak Covid-19 pada Pendidikan di Indonesia: Sekolah, Keterampilan, dan Proses Pembelajaran. SALAM: Jurnal Sosial Dan Budaya SyarI, 7(5), 395-402. https://doi.org/10.15408/sjsbs.v7i5.15314

Uun Almah, M. Ilyas Thohari, Y. F. L. (2020). Pemanfaatan Teknologi Pembelajaran Pendidikan Agama Islam Di Tengah Masa Pandemi Covid-19 Berbasis Social Distancing Di SMKN 5 Malang. VICRATINA: Jurnal Pendidikan Islam, 5(10), 134-143.

http://www.riset.unisma.ac.id/index.php/fai/article/view/7720

Widiyono, A. (2020). Efektifitas Perkuliahan Daring (Online) pada Mahasiswa PGSD di Saat Pandemi Covid 19. Jurnal Pendidikan, 8(2), 169-177. https://doi.org/10.36232/pendidikan.v8i2.458

Yuliana, Y. (2020). Analisis Keefektivitasan Pemanfaatan E-Learning Sebagai Media Pembelajaran Pendidikan Agama Islam Pada Masa Pandemi Corona (Covid-19). SALAM: Jurnal Sosial Dan Budaya Syar-I, 7(10), 875-894. https://doi.org/10.15408/sjsbs.v7i10.17371

Yusuf, M., Hamdani, Siregar, A. P., \& Siregar, F. N. (2020). Implementasi Pendidikan Agama Islam di Masa Pandemi Covid-19. Maslahah Jurnal Pengabdian Masyarakat, 1(1), 38-48.

https://doi.org/10.30596/maslahah.v 